\title{
EL ESTUDIO DE LA CULTURA Y SU RELACIÓN CON EL RENDIMIENTO ORGANIZACIONAL
}

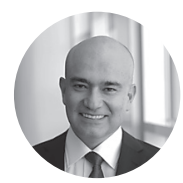

\author{
JORGE M. GIL \\ - Profesor de Desarrollo de Proyectos Internacionales \\ Carrera de Administración y Negocios Internacionales \\ Facultad de Negocios, UPC
}

Cada vez más análisis y autores coinciden con el incremento de la complejidad para ejercer la gerencia como una actividad que permita obtener los resultados que esperan las organizaciones. A la dificultad para diferenciar sus propuestas de valor debido al incremento de la competencia, las empresas deben sumar la rapidez en los cambios e innovación que viene de diversos frentes; la adopción de nuevos escenarios y tecnologías; la convivencia de diferentes generaciones y culturas dentro de las organizaciones; y los entornos locales e internacionales en permanente inestabilidad, por factores económicos, sociales, jurídicos, entre otros. Por otro lado, si hay algo que ha permanecido inalterable con el paso del tiempo en el ámbito de la gerencia es la necesidad y la presión por lograr un buen desempeño de los trabajadores y la organización en su conjunto. En el presente artículo hacemos en primer lugar un breve repaso de la evolución del concepto de "cultura" para relacionarlo luego con los de "cultura organizacional" y "rendimiento organizacional", haciendo especial énfasis en la relación causa-efecto de estos últimos.

A través de los años, el estudio de la administración ha ido incorporando cada vez más a la cultura organizacional como una forma de amalgamar diferentes puntos de vista que explican el comportamiento de individuos trabajando y viviendo en conjunto, remontándose los primeros artículos científicos sobre el tema hacia finales de la década del 70 y principios de los 80 . El número de publicaciones sobre el particular es vasto.

En paralelo y por esa misma época, el estudio de la cultura organizacional se vio además fuertemente impulsado por el auge de grandes empresas japonesas, a las cuales se consideraba como poseedoras de un modelo operativo superior, en un momento en el que se estudiaba de forma predominante la estructura formal para entender a las organizaciones. Es entonces cuando las investigaciones académicas profesionales empiezan a examinar la influencia que puede tener la penetración de diferentes culturas nacionales en una misma empresa.

Siguiendo a Ouchi y Wikins (1985), situamos al estudio contemporáneo de la cultura organizacional como la continuación de los estudios anteriores realizados en el ámbito de la sociología organizacional, donde se encontraba una tensión constante entre quienes creían en la capacidad de las organizaciones de crear un orden racional y aquellos que vivían el día a día de la vida organizacional.

En tiempos más modernos, por otro lado, Hofstede y Minkov (2010), definen a la cultura como algo aprendido, no innato, que es resultado del entorno social del individuo, más que de los genes. Como puede verse en la figura 1, Hofstede \& Minkov proponen 3 niveles de singularidad en programación mental:

Figura 1

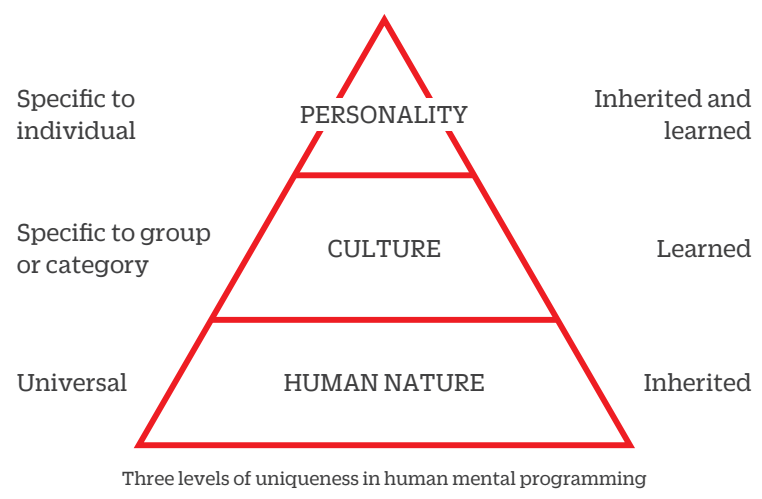

Fuente: Hofstede y Minkov (2010).

Vemos pues así que la naturaleza humana es lo que todas las personas tienen en común, sin importar su lugar de origen o la sociedad en la que crecieron y se desenvuelven; y en ella encontramos la capacidad para sentir miedo, enfado, alegría, tristeza, la necesidad de convivir con otras personas y de jugar y ejercitarse. La cultura, bajo esta misma perspectiva, es la que establece lo que cada individuo hace con estos sentimientos, es decir, cómo expresa su miedo, alegría, etc.

VEMOS PUES ASÍ QUE LA NATURALEZA HUMANA ES LO QUE TODAS LAS PERSONAS TIENEN EN COMÚN, SIN IMPORTAR SU LUGAR DE ORIGEN O LA SOCIEDAD EN LA QUE CRECIERON Y SE DESENVUELVEN.. 
La personalidad de un individuo, por otro lado, es su conjunto único y personal de programas mentales que no necesitan ser compartidos con ningún otro ser humano y está basada en rasgos que son parcialmente heredados y parcialmente aprendidos, es decir modificados por experiencias colectivas o individuales.

Entrando ya en el estudio de las manifestaciones que reflejan las diferencias culturales entre los individuos, encontramos que diversos autores las agrupan en símbolos, héroes, rituales y valores, rescatando para este artículo la diagramación realizada por Hofstede (2001), en la que los valores constituyen la esencia de la cultura e influyen directamente en la práctica y evolución de las otras tres manifestaciones:

\section{Figura 2}

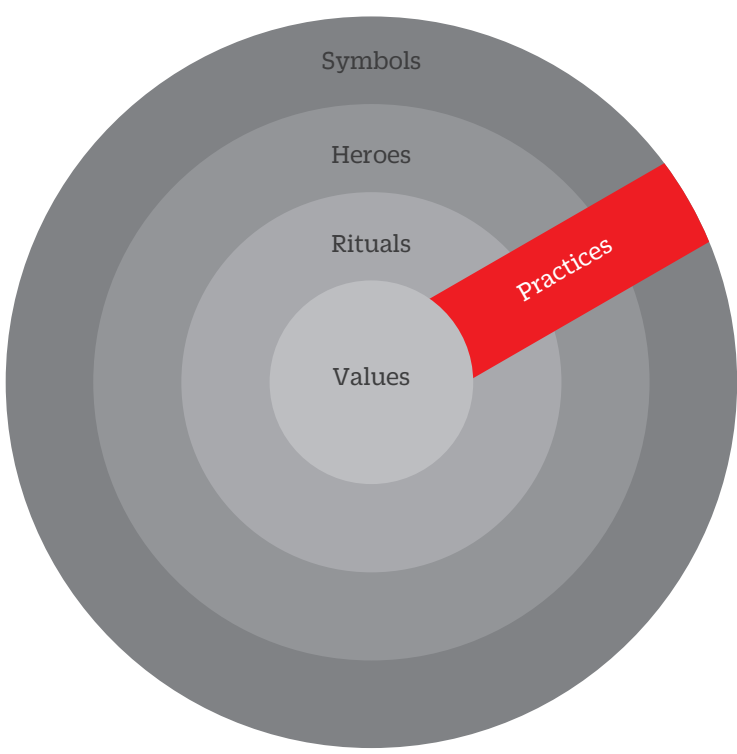

Fuente: Hofstede (2010)

Considerando que cada individuo puede tener su propia forma de asumir y desarrollar sus valores, ritos, héroes y símbolos, la cultura organizacional se convierte en una especie de pegamento que mantiene de cierta manera unidos y cohesionados a todos los individuos de la misma. Las grandes corporaciones están, en ese sentido, cada vez más y más conscientes de la importancia del desarrollo de una cultura organizacional para llevar a cabo un mejor control, coordinación e integración de sus unidades de negocio o subsidiarias

Como concluye Anthony S. Boyce (2015), la cultura organizacional ha sido desde siempre descrita como un motor en el rendimiento de una empresa, siendo estudiada como la relación "cultura-rendimiento", desde sus primeras menciones en documentos de investigación hasta la acumulación de evidencias puestas de manifiesto en investigaciones más recientes. Sin embargo, las investigaciones a la fecha se han quedado en cierta forma cortas en su intento de establecer de manera
VEMOS PUES ASÍ QUE LA NATURALEZA HUMANA ES LO QUE TODAS LAS PERSONAS TIENEN EN COMÚN, SIN IMPORTAR SU LUGAR DE ORIGEN O LA SOCIEDAD EN LA QUE CRECIERON Y SE DESENVUELVEN...

concreta una causa-efecto entre la cultura organizacional y el rendimiento, ya que, de manera alternativa, se ha descubierto a la vez que podría ser que el rendimiento de una organización sea el que dé forma a la cultura organizacional, que la cultura organizacional y el rendimiento estén relacionados de forma recíproca o que ambos sean causados por una tercera variable.

Diversos investigadores han descrito a la cultura como algo adaptativo y que sienta las bases para una relación recíproca con el rendimiento. Tal vez la más notable descripción de la relación entre cultura y rendimiento sea la que propone Schein (2004) como descripción de la evolución de la cultura a través del ciclo de vida de una organización:

\section{Figura 3}

Tres Niveles de Cultura (Schein)

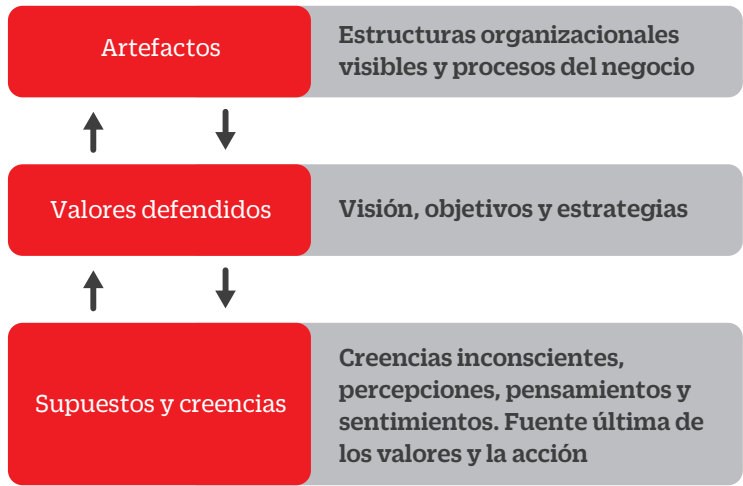

Fuente: Schein (2004)

La evolución de la cultura en el ciclo de vida es explicada de esta forma como un respaldo a la idea de la existencia de una relación recíproca entre cultura y rendimiento, donde al inicio la cultura refleja principalmente los valores de su líder o fundador y luego, estos valores son desafiados demandando el esfuerzo de la organización para adaptarse a los problemas internos y externos que encuentre. Sin embargo, como señala Boyce (2015), hay algunos factores que limitan la influencia de esta retroalimentación. En primer lugar, los individuos tienden a atribuir sus fracasos y los de sus grupos a factores externos y no internos, lo que sugiere que el cambio cultural es poco probable que ocurra a menos que las personas en la organización vean a la cultura como parte del problema. En segundo lugar, Schein describe cómo la habilidad para cambiar una cultura se ve limitada a 
medida que una organización alcanza la madurez. Y tercero, las características de la cultura misma pueden dirigir a la organización hacia la resistencia al cambio.

Estos factores en su conjunto, pueden hacer que en un momento determinado, una organización limite o debilite el enlace de retroalimentación que debe existir, lo que debe ser tomado muy en cuenta por las organizaciones, ya que una interacción dinámica entre cultura y efectividad organizacional es fundamental para un funcionamiento basado en procesos.

\section{REFERENCIAS}

Boyce, A. S., Nieminen, L. R., Gillespie, M. A., Ryan, A. M., \& Denison, D. R. (2015). Which come first, organizational culture or performance? Journal of Organizational Behavior, 36, 339-359.

Hofstede, G., \& Minkov, M. (2010). Cultures and Organizations: Software of the Mind (3ra ed.). USA: McGraw-Hill.

Hofstede, G. (2001). Culture's Consequences: Comparing Values, Behaviors, Institutions and Organizations Across Nations. Los Angeles, LA: Sage.

Ouchi, W. G., \& Wikins, A. L. (1985). Organizational culture. Annual Review of Sociology, 11(1), 457-83.

Schein, E. H. (2004). Organizational Culture and Leadership. San Francisco, CA: Jossey-Bass. 